\title{
A Comparative Study of Absolute Liability Offense in Iran and the UK
}

\author{
Seyed Mohammad Mousavi ${ }^{1}$, Arash Babaei ${ }^{2}$, Shamsollah Khatami ${ }^{3}$ \& Yousef Jafarzadi ${ }^{4}$ \\ ${ }^{1}$ Islamic Azad University of Ilam, Ilam, Iran \\ ${ }^{2}$ Islamic Azad University E-campus, Tehran, Iran \\ Correspondence: Seyed Mohammad Mousavi, Islamic Azad University of Ilam, Ilam, Iran. E-mail: \\ seyedmohammad.mousavi1991@yahoo.com
}

Received: December 15, 2015 Accepted: January 21, 2016 Online Published: February 23, 2016

doi:10.5539/ass.v12n3p135 URL: http://dx.doi.org/10.5539/ass.v12n3p135

\begin{abstract}
One characteristic of the force of law in the country, the integrity of the rules in all areas of all aspects of creation into account the distinction between crime and the crime and failed or incomplete in acts of crime and crime as the withdrawal. In this respect the rules on penalties culpability in the crime has been proposed that the content of the crime with absolute responsibility of these categories has manifested. Under the Articles 144 and 145 of the Latest version Islamic criminal law (2013), Create unintentional offenses, subject to verification of the fault committed. In crimes ranging from quasi-intentional unintentional deviation as retaliation book rules apply. Legislator to commit a fault, the reason for the error is considered criminal, which has always been considered an objective measure and a ruler (in Article 145), while the common law under subsection (1) "criminal law to crimes" adopted 1981 crime start as the offense is punishable total. This study showed that certain similarities between the laws. In this context, the two internal laws and the common law can be found, in which the underlying offense of absolute liability is not fixed in the courts. Always treat judges and lawyers in the face of legal texts are not consistent because of the lack of transparency and clarity of the rules. In particular, in the common law, when a crime for the first time in cour $t$, and a warrant has been issued about it in terms of predicting the law and with regard to the interpretation of judges, procedural difference is more tangible.
\end{abstract}

Keywords: absolute liability offense, crime incomplete, unfinished crimes

\section{Introduction}

Offenses can include all of these elements, or only one of these elements as have the background. The crimes which Iran called "purely material Crimes" and the rights of the common law of "absolute liability offense" called.

Element is the absolute responsibility of the themes that focus on the paper and researcher tried to comprehensive review of the axis and a comparative study of Iran's rights to England. Every crime is composed of two elements, spiritual and material (except legal element) should be above 2 elements exist to prove the charge, but in view of the importance of certain crimes legislator's intent in some cases assumed, for example, on Bank Check without the need to prove intent is not valid, the presumption that a person is ill and does not have to prove it (Langroodi, 2009, p. 24.)

In today's criminal law, criminal liability is subject to criminal behavior and appearance of human thought as long as obscene, external appearance does not find a bad idea in the human mind is hidden, the man is not permitted and the fact, even in where the man to admit his criminal intent is proven this way, the manifestation of criminal intent or negligence criminal act or practice that is foreign, is an element of crim (Nasab, 2010, p. 23)

In Internal laws, the issue of crime and the concept that only the material discussed above, can be also introduced the notion that, charges are not guilty to involuntary withdrawal by foreign barriers (crime start) Or fail due to reasons (Offence) or be impossible to obtain due to crime (crime impossible), the same amount of action that is indicative of ill offenders will be subject to criminal penalty (Farhodinia, 2001, p. 177).

In international law, crimes that do not meet the spiritual element are the absolute liability offenses. To achieve purely material crimes alone crime is not necessary to prove the spiritual component. In all crimes, including intentional and non-intentional, and through lack of will by the person committing the crime is committed realization is canceled and will have to act with criminal intent or fault of the crime is committed by a criminal 
and is not possible to (Forumand, 2010, p. 114).

\section{The Concept of Crime and the Offenses}

Crime is interpreted literally means sin and error (Persian Arabic dictionary, 1414, p. 255)

Crime in terms of religious and legal texts prohibited any lawful which God determine temporal punishment in this world (such as, punishment, retribution, atonement, expiation) or punishment in other world (metaphysical) decreed, ranging from doing something that is forbidden in Islam or leave out something that does not matter.

Crime survey revealed that crime in the community in various aspects such as murder, theft, kidnapping, rape and violations, fraud and crime on the topic of cognitive complexity and context of the emergence of different that given the level of losses and social vulnerability of these crimes, monitor and assess the areas of behavioral factors such as the types of character, mental condition, age and gender of the perpetrators of the crimes, the reasons and motivations approach resulting in crimes, etc., can be effective in reducing them (Rahiminezhad, 2013, p. 4).

For the punishment of purely material Crimes, need to meet the spiritual element, but it certainly makes obtaining the absence of the accused is acquitted. If there is an element of general crime, crime cannot be achieved and there is no reason for the penalty (Forumand, 2010, p. 63).

Each of these stages has different circumstance. The Legislator because a reward to those who are on the path of crime and the last traces of humanity or remorse in them the desire to be effective and prevent them from committing crimes Rejection voluntary disposal of culpability as a person who in the course of committing a crime if he knows that even if he is waiting for the penalty deter crime continues Act 1997 and all that.

In Latest version Islamic criminal law (2013), the difference between the intention of committing a crime and the crime is clearly marked

3 study theoretical perspectives absolute liability offense

In examining the legal books can be deduced that a crime has two elements the second element of the crime act. The means of spiritual material (material element), external fulfillment is an illegal act which can be in the form of a verb (like theft and murder), omission (for example, The doctor refused to treat the patient and give the obligatory charity), speak (for example, insulting and cursing), leaving about (like refusing to testify, which would be wrong right), keep some objects (for example, guns allowed), Mode Lifestyle (such as vagrancy) or mood (such as addiction).think to dose the crime abroad may not be realized as long as the crime is not (rahiminezhad, 2013, p. 5)

Sometime the intention of committing a crime had not external condition, for example, criminals colluding. But the legislation as a threat to social order and is considered a crime. Lawyers such crimes, which prevent them from achieving bigger prevent crime, "a crime deterrent," said (Ardebili, 2010, p. 8).

The need for material element of the crime, does not mean they always have all the components of the material element to achieve crime is reached, it may be out of action, due to external obstacles (and not withdrawn offender) has not led to the desired result, their criminal and subject to specific criminal. In this case, the offender, as the start of a crime, to be punished (Taheri nasab, 2010, p. 17).

If the act or omission was done by cannot be considered as a criminal offender just because the law is not an offense to commit a criminal.

The realization of crime material is subject to the outcome of criminal offenses, such as murder and theft, but the official crime, the performance of the criminal, regardless of the result, the views of the legislator, is a crime, such as counterfeit (Aliabadi, 2012, p. 13).

crime in addition to the material and legal aspects, personal and spiritual aspect of it more and more often in determining instances of crime and criminal conquest of the greatest uncertainties and differences in the realization of crime spiritual element there

\section{Absolute Liability Offense in Internal Law}

There are different stages of material elements for the realization of any crime committed in order to achieve their purpose of travel must be otherwise may his actions are subject to start covering the crime, the crime of the crime is associated with infertility impossible.

Article 61 and 611 of Latest version Islamic criminal law (2013) said that, Action Step crime reflects the implementation of criminal thinking and demonstrates that commit mentally ready for operation have been criminal. 
For example, under Article 187 of Latest version Islamic criminal law (2013) said that, any person or group that map to overthrow the Islamic government to take into account for this purpose as well as those who provide weapons, explosive materials, funding and selection of effective knowledge or the means and weapons of their the battle of the Islamic system and are corrupt on earth)) (Thorburn, 2011, p. 13).

The emergence of the material element of the crime in the operation is that in case of non-fulfillment of a crime committed voluntarily withdrawal complete lack of involvement of foreign agents to realized the crime.

For example, someone who entered his home to steal another's property, and after collecting furniture for the home owner and his pursuers fled waking up, the offender shall for robbery, but if you non-fulfillment of the will of the result discussion was impossible to steal, and if the offense is a particular cause for voluntarily withdrawal from the penalty commuted.

As Clause 2, Article 41 of Latest version Islamic criminal law (2013) said that, who is the beginning of a crime, if they wish to leave it out crime action is the cause of mitigation of the punishment will be, but if the same amount of work the executive is also a special crime crime that resulted in mitigation of the punishment is voluntarily withdrawal (Ramsay, 2012, p. 41).

Latest version Islamic criminal law (2013) In relation to purely material crime and its importance with the adoption of transparent material, especially Article 144, 145 and 217, a breakthrough in the field of law is a crime start

\section{Offense of Absolute Liability at Common Law Rule in England}

The common law in England, a progressive law on absolute liability offenses is a defining element. According to this law, the person convicted in any crime, except if it is contrary to the criminal nature of the act itself and with the exception of crimes punishable by death entered and crimes against crime and the punishment of the offenses punishable by entering start, imprisonment or fine to the extent that it does not exceed the total mass punishment (Bhavani, 2010, p. 119).

In the common law and in the area of criminal offenses, to impose punishment on criminals, it is essential that the physical element and the mental element of the verb to exist simultaneously. But there are exceptions in the law that legislation to prevent the commission of some dangerous behavior and protection of the public interest, has to make provisions for the difficulty of proving that it act in bad faith, high costs, prolongation of procedure and the absolute has banned (Jareborg, 2005, p. 44).

This process of "absolute liability or criminal liability without fault" is called, it will punish the guilty, although the psychological element is not necessary; in other words, whether or not his purpose in violation of law, the principle of criminal law makes the penalty in the event of a "no fault" is imposed (Surendra, 2015, p. 3).

In the common law, the purpose of the absolute responsibility, impose penalties, regardless of the fault committed, and in general, the need to prove the mental element is, therefore, the intention of the person presumed to be treated as a violation of the law (Stefani, 1386: 115). Hence, absolute liability can be charged to the concept of "real" accepted responsibility.

It is accepted in English law and in accordance with section (1) "the crime of criminal law" passed in 1981, began as a completed crime punishable offense. On the other hand, some argue that we the people by their deeds and not merely the results of their efforts, we will be judged. Student with a big effort to deliver bad test sheet, score is bad and lazy students and low contrast what happened to all of the questions will be answered says a good score. Of course, the same approach should be adopted in the world of law. This is why in England, the courts are not allowed to practice using their authority to start less than the total perpetrators of crimes are given (Sumeet, 2014, p. 18).

Absolute responsibility in the broad sense refers to crimes in which there are no psychological components (Farmer, 2000, p. 226).

In no intention of committing such criminal acts and negligence and recklessness have also done him, but to pass legislation and criminalization of the behavior of different reasons, committed a punishable.

As outlined above causation in criminal law is understood as a chain of events linked to each other - it is a link between the defendant's act and the consequence which occurred as a result of that act. As causation represents an integral element of result crimes - the one to be proved, the law developed certain tests to establish it (Yaffe, 2010). They represent a two-stage process or two tests to be applied in succession. The first test is factual causation and the second one is legal causation (Dubber, 2001, p. 2).

Thus, it is seen from the outset that causation is effectively a mixture being a question of fact and a question of 
law at the same time or, in other words, causation is a factual issue to begin the analysis and a legal one to finalise the findings. At the same time, it is arguable that legal causation itself is a facade of a chosen approach to allocating blame. Indeed, it is submitted that criminal law itself is a mechanism for allocating blame. In turn, allocation of blame is a process which is almost inevitably based on moral and policy considerations (van den Haag, 2009, p. 33).

\section{A Comparative Study of Absolute Liability Offense in Iranian Law and Common Law Criminal Absolute Responsibility}

The Latest version Islamic criminal law (2013) 1392 in conjunction with the approval of guilt on the importance of transparent material, especially Articles 144 and 145 raised. Legislator to commit a fault, statistics on criminal known error, which has always been considered an objective measure and a ruler (in Article 145) that the unintentional offense it is not necessary to go to the subjective criteria, ie there is no need to analyze and research get the mental and spiritual person, namely if the only thing it did not traditionally done, and this leads to accident and crime, by itself, is sufficient to establish the mental basis, (that is committed to working It should not be done traditionally or to refrain from committing what have traditionally was doing it, because it is the fault of the person), ie with an objective criterion, is to establish the mental element (which is actually about very comfortable intentional crime has been.

However, those absolute liability offenses in common law different criteria for recognition of other crimes have raised. The first criterion relates to the offense of actual crimes (bad guy) and disciplinary offenses.

The second criterion in determining the punishment. The third criterion is the text of the law, judges according to the text of the law should discover that the legislator of the state of law, creating an absolute liability offense, or not? The fourth criterion, compared to phrases and words, sometimes with the help of the issues surrounding the judge can do to achieve recognition. The fifth criterion, crime history of previous laws and legal resources. The sixth criterion, the general defense of negligence in the context of the law. Sometimes the legislator believes the crime and the circumstances and characteristics of the defendant to prove the absence of negligence states that they could easily escape punishment.

The similarity of the two Internal laws and the common law can be found, in which the underlying offense of absolute liability is not fixed in the courts. Always treat judges and lawyers in the face of legal texts is not consistent because of the lack of transparency and clarity of the rules. In particular, in the common law, when a crime for the first time in court, and a warrant has been issued about it in terms of predicting the law and with regard to the interpretation of judges, procedural difference is more tangible.

\section{References}

Dubber, M. D. (2001). Policing Possession: The War on Crime and the End of Criminal Law. Journal of Criminal Law and Criminology. Punishing Criminals: Concerning a Very Old and Painful Question. Basic Books. ISBN 0-8191-8172-2.

Farhoodinia, H. (2001). Comparative analysis of the incomplete crimes (1st ed., p. 20). Publishing Afterglow.

Farmer, L. (2000). Reconstructing the English Codification Debate: The Criminal Law Commissioners, 1833-45. Law and History Review, 18(2).

Forumand, M. (2010). The Islamic Republic of Iran for the crime of criminal law (p. 50). Article Jzavjrm Master of Law, Faculty of Humanities, University of Madras.

Hensley, T. R. (2001). The Boundaries of Freedom of Expression \& Order in American Democracy (p. 153). Kent State University Press.

Jaafari Langroodi, M. J. (2009). Terminology rights, Tehran, knowledge treasure (No. 3811).

Jareborg, N. (2005). Criminalization as Last Resort (Ultima Ratio). Ohio State Journal of Criminal Law, 2, $521-34$.

Nasab, T. (2010). Causality in criminal law in Iran and England (1st ed.). Tehran: Publisher of Justice.

Ramsay, P. (2012). The Insecurity State: Vulnerable Autonomy and the Right to Security in the Criminal Law. Oxford: Oxford University Press.

Thorburn, M. (2011). Criminal Law as Public Law. In Duff and Green (pp. 21-43).

Yaffe, G. (2010). Attempts in in the Philosophy of Action and the Criminal Law. Oxford: Oxford University Press. 


\section{Copyrights}

Copyright for this article is retained by the author(s), with first publication rights granted to the journal.

This is an open-access article distributed under the terms and conditions of the Creative Commons Attribution license (http://creativecommons.org/licenses/by/3.0/). 